\title{
A model of the seasonal dynamics of biomass and production of the seagrass Posidonia oceanica in the Bay of Calvi (Northwestern Mediterranean)
}

\author{
Khalid Elkalay ${ }^{\mathrm{a}, *}$, Constantin Frangoulis ${ }^{\mathrm{a}}$, Nikos Skliris ${ }^{\mathrm{b}}$, Anne Goffart ${ }^{\mathrm{a}}$, \\ Sylvie Gobert ${ }^{\mathrm{c}}$, Gilles Lepoint ${ }^{\mathrm{c}}$, Jean-Henri Hecq ${ }^{\mathrm{a}}$ \\ ${ }^{a}$ Ecohydrodynamics, University of Liège, Institute of Physics (B5), Sart Tilman, B4000 Liège, Belgium \\ ${ }^{\mathrm{b}}$ Department of Meterology, Oceanography Group, University of Athens, Athens, Greece \\ c Oceanology, University of Liège, Sart Tilman (B6), B4000 Liège, Belgium
}

Received 19 October 2001; received in revised form 5 August 2002; accepted 4 March 2003

\begin{abstract}
Modelling of seagrasses can be an effective tool to assess factors regulating their growth. Growth and production model of Posidonia oceanica, the dominant submerged aquatic macrophyte occurring in the Bay of Calvi (Corsica, Ligurian Sea, Northwestern (NW) Mediterranean) was developed. The state variables are the above- and below-ground biomass of $P$. oceanica, the epiphyte biomass, and the internal nitrogen concentration of the whole plant. Light intensity and water temperature are the forcing variables. The model reproduces successfully seasonal growth and production for each variable at various depths (10, 20 and $30 \mathrm{~m}$ ). The model can simulate also a number of consecutive years. Sensitivity analysis of model's parameters showed that the maximum nitrogen quota $n_{\max }$ rate is the most sensitive parameter in this model. The results simulations imply that light intensity is one of the most important abiotic factors, the diminution of which can cause an important reduction in seagrass density.

(C) 2003 Elsevier B.V. All rights reserved.
\end{abstract}

Keywords: Seagrass; Posidonia oceanica; Biomass; Production; Growth model; Shading effect; Sensitivity; Bay of Calvi

\section{Introduction}

Seagrass meadows are found in many coastal areas around the world. They help the stabilisation of sediments, provide nursery habitats for fish (Orth and Van Montfrans, 1984), contribute significantly to the primary production, and play an important role in the nutrient budget of the coastal marine ecosystems (Oshima et al., 1999). They can take nutrients both through below- and above-ground biomass, and can

\footnotetext{
* Corresponding author. Tel.: +32-4-366-3647; fax: +32-4-366-2355.

E-mail address: khalid.elkalay@wanadoo.be (K. Elkalay).
}

grow under low nutrient concentrations (Iizumi and Hattori, 1982). The presence of large amounts of seagrass influences nutrient cycling.

Posidonia oceanica meadows extend from near the surface down to $40 \mathrm{~m}$ depth (Bay, 1984). Knowledge of the P. oceanica life cycle observed in the Bay of Calvi (Bay, 1984; Gobert et al., 1995) including several aspects of their physiology is well studied (e.g. Alcoverro et al., 1995, 2000; Zupo et al., 1997). As in most marine phanerogams, the leaves of $P$. oceanica support many plant and animal epiphytes, which can reach up 20-30\% of the biomass of the leaves (Gobert et al., 1995). The epiphytic community probably plays an important role in the productivity and growth 
patterns of the host plant in terms of competition for available light, energy and nutrients (Mazzella and Ott, 1984; Libes and Boudouresque, 1987; Mazzella et al., 1989, 1992; Pergent et al., 1994; Alcoverro et al., 1997a).

Light and nutrients represent the input of energy and matter for growths, and determine the annual production (Dennison et al., 1987; Duarte, 1990, 1991; Lorenti et al., 1995; Gallegos and Kenworthy, 1996). Therefore, the total annual production is mainly influenced by light and nutrients (Pirc, 1985a,b; Williams and Ruckelshaus, 1983), while the seasonal production pattern is affected by temperature (Zupo et al., 1997). This represents a modulating factor which varies in different bodies of water, and influences the seasonal growth pattern (Buia and Mazzella, 1991; Zupo et al., 1997).

Several works have produced simulation models for seagrass dynamics (Short, 1980; Zimmerman et al., 1987; Bach, 1993; Madden and Kemp, 1996; Bach et al., 1997; Bocci et al., 1997; Coffaro and Sfriso, 1997; Zupo et al., 1997; Elkalay et al., 2000). The majority of the models integrating seagrass are made in lakes (e.g. Asada and Van Bon, 1999), and most are based on carbon, few are based on nitrogen, they do not make the distinction between nitrate and ammonium, and in general the models are established for Zostera marina (e.g. Bach, 1993), and do not take into account the biomass of the rhizomes. To our knowledge for $P$. oceanica, there are only two models: one concerning growth of only above-ground biomass of Posidonia based only on the temperature (Zupo et al., 1997) and the other concerning the architecture of this plant (Molinaar et al., 2000). The models available on the seagrasses did not completely meet our needs. In addition to this lack of modelling on the Posidonia, it is necessary to note that this plant is different from the other seagrass about growth and physiology. This difference makes difficult the application of a model made on other species and other areas. Consequently, we considered it necessary to develop our model. The model of $P$. oceanica presented here fills a gap in existing models in that it is a whole-plant approach; for example, changes in below-ground biomass are explicitly included.

The major aims of this research are to test preliminary models for $P$. oceanica and epiphytes growth, and to consider the influence of change in forcing func- tions such as light. The sensitivity of the model to altered light regimes was evaluated by varying the water depth and the average annual water column light attenuation. Effects of water depth were simulated by fixing the depth at 10,20 and $30 \mathrm{~m}$. Therefore, the attenuation coefficient was varied through fixed values.

The principal aim of the present study was to quantify the development of $P$. oceanica by modelling its growth and biomass. The mathematical model is based on the analysis of the growth process in the Bay of Calvi. This study represents part of larger model to quantify the dynamic relationships between the different compartments of the bay ecosystem, in which a model considering the physiology of the whole plant was required. Development of the model will also help to identify avenues of research important to further development of seagrass models.

\section{Model description}

The components of the ecosystem are represented by compartments, and interactions are described by linking compartments (Fig. 1). The state variables are: leaf biomass $(L)\left(\mathrm{g} \mathrm{DW} \mathrm{m}^{-2}\right)$; below-ground biomass $(R)\left(\mathrm{g} \mathrm{DW} \mathrm{m}^{-2}\right)$; nitrogen concentration in seagrass $\left(Q_{\mathrm{n}}\right)\left(\mathrm{mg} \mathrm{N} \mathrm{mg}^{-1} \mathrm{DW}\right)$; and epiphyte biomass $(E)$ $\left(\mathrm{g} \mathrm{DW} \mathrm{m}^{-2}\right)$. The major nitrogen sources for seagrasses are $\mathrm{NH}_{4 \mathrm{w}}{ }^{+}$and $\mathrm{NO}_{3 \mathrm{w}}{ }^{-}$in the water column for leaves and $\mathrm{NH}_{4 \mathrm{w}}+$ in sediment pore water for below-ground biomass (Touchette and Burkholder, 2000).

P. oceanica is exposed to a broad range of physical factors, e.g. temperature and light. The adaptation of the plant to these different environmental conditions should rely on the ability to respond to external constraints, as well as on inner regulating mechanisms (Ott, 1979). The balance between the intrinsic and extrinsic factors is crucial for the success of growth and the stability of the meadow.

Epiphytes were modelled as an autotrophic community dominated by microflora (Wetzel and Neckles, 1986) although, in the Bay of Calvi, epiphyte fauna constitute between 10 and $30 \%$ of the total epiphytes biomass (Lepoint et al., 1999). Epiphytes growth is influenced by the same abiotic factors, which influence the seagrass host (e.g. Borum, 1985; Mazzella et al., 1989). 


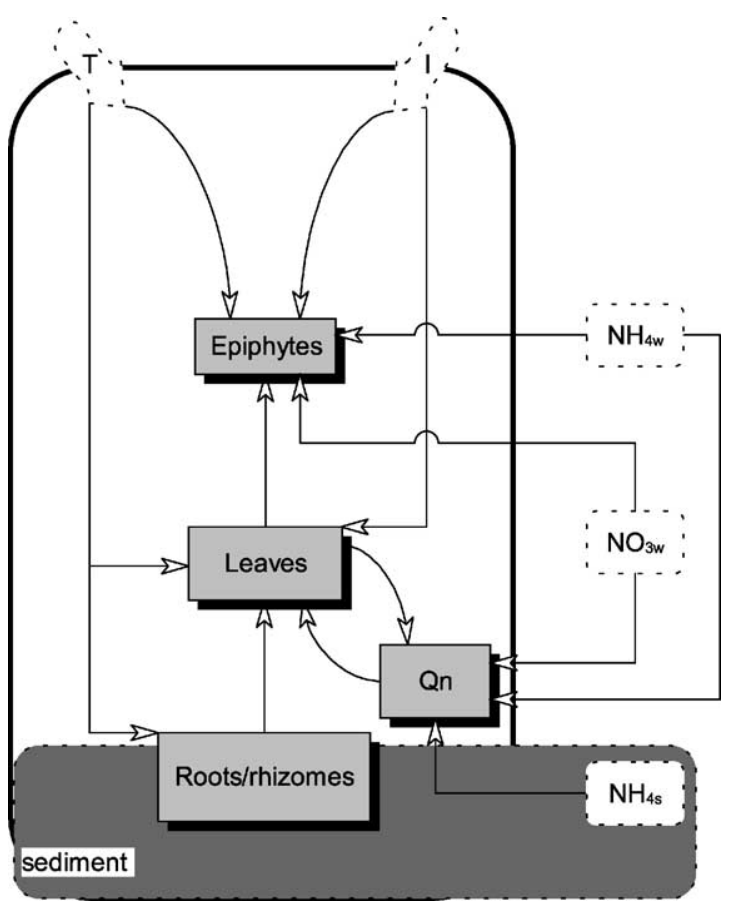

Fig. 1. Diagrammatic representation of interactions between main ecological state variables. $(T)$ temperature, $(I)$ irradiance, $\left(Q_{\mathrm{n}}\right)$ nitrogen concentration in seagrass, $\left(\mathrm{NH}_{4 \mathrm{w}}\right)$ ammonium water column, $\left(\mathrm{NO}_{3 \mathrm{w}}\right)$ nitrate water column, $\left(\mathrm{NH}_{4 \mathrm{~s}}\right)$ ammonium in sediment pore water.

In primary producers, the net growth is a result of the balance between productive processes, which incorporate biomass, and degradative processes, which consume biomass. The variation of the above-ground (Eq. (1)), below-ground (Eq. (2)) and epiphytes (Eq. (3)) biomass can be described by the differential equations:

$$
\begin{aligned}
\frac{\mathrm{d} L}{\mathrm{~d} t} & =(\text { Grol }- \text { transl }- \text { Resl }) \times L+\text { transr } \times R \\
\frac{\mathrm{d} R}{\mathrm{~d} t} & =(\text { Gror }- \text { transr }- \text { Resr }) \times R \\
\frac{\mathrm{d} E}{\mathrm{~d} t} & =(\text { Groe }- \text { Rese }) \times E+\text { transl } \times L
\end{aligned}
$$

where Grol, Gror and Groe are the specific growth rate coefficients $\left(\right.$ day $\left.^{-1}\right)$ for leaves, below-ground biomass and epiphytes, respectively. Resl, Resr and Rese are the specific respiration rate coefficients $\left(\mathrm{day}^{-1}\right)$ for leaves, below-ground biomass and epiphytes, respec- tively. transl is the translocation rate from leaves to epiphytes and transr is the translocation rate from belowto above-ground biomass.

The strong seasonality of seagrass growth has been demonstrated to be coupled to seasonal variations in light (e.g. Zimmerman et al., 1994) and temperature (Buia and Mazzella, 1991; Zupo et al., 1997), nutrient availability (Harlin and Thorne-Miller, 1981; Orth, 1977), and space limitation. The leaf, below-ground biomass and epiphyte growth rate coefficients were calculated, respectively, as a fraction of the maximum rate (Eq. (4)):

Grol $=$ Groml $\times f\left(I_{z}\right) \times f(T) \times f(N) \times f(S)$

where Groml is the leaf maximum specific gross growth rate coefficient $\left(\right.$ day $\left.^{-1}\right)$; and $\mathrm{f}(\cdot)$ are the dimensionless functions describing the effects of light $\left(I_{z}\right)$, temperature $(T)$, nutrient $(N)$ and space $(S)$ on growth. The same equation was used for below-ground biomass and epiphytes, with Gromr and Grome the root and epiphyte maximum specific gross growth rate coefficients, respectively. The influence of limiting factors is taken into account in a multiplicative formulation for both communities. The assumption of the multiplicative factors is that light, temperature, nutrients and space act independently on the growth. In models that in principal are similar to the model presented here, the law of multiplicative factors has been successfully applied (e.g. Bach, 1993).

Light availability is the most important factor regulating the depth distribution, abundance and productivity of submerged aquatic macrophytes (Zimmerman et al., 1994). The basic attenuation equation, including extinction due to turbidity and water colour is represented as an exponential decrease in light intensity with depth. The equation of water column light attenuation is given by Beer's Law:

$I_{z}=I_{0} \mathrm{e}^{-k_{z} \times z}$

where $k_{z}$ is water column light attenuation coefficient, $I_{z}$ is the irradiance at depth $z(10,20$ and $30 \mathrm{~m})$ within the water column and $I_{0}$ is the surface irradiance. The response to light intensity is formulated as:

$$
f\left(I_{z}\right)=\frac{I_{z}}{\mathrm{kel}+I_{z}}
$$

where kel is the irradiance half-saturation constant. According to this formulation, growth is a linear 
function of light at low intensities, then saturates and asymptotically approaches their maximum at higher intensities. The same equation was used for belowground biomass and epiphytes, with kee the irradiance half-saturation constant of epiphytes.

Temperature $(T)$ can significantly affect the rates of physiological processes such as photosynthesis and respiration. Effects on the leaf, root and epiphyte growth have been described using:

$f(T)=\exp \left[-\left(\frac{T-\text { Toptl }}{\text { stl }}\right)^{2}\right]$

where Toptl is the leaf optimal growth temperature, and stl is the leaf growth dependence on temperature. The same equation was used for below-ground biomass and epiphytes with Toptr and Topte the optimal growth temperature, and str and ste are the associated growth dependence on temperature, respectively.

The ability of $P$. oceanica to assimilate inorganic $N$ varies in response to internal (tissue age and type) and external (environmental) factors (Kraemer et al., 1997). Internal nitrogen content is simulated by considering uptake from water and sediment and the consumption for growth (controlled with a feedback effect). Kinetics nutrient uptake by $P$. oceanica, was assessed using a linear dependence of growth from average nitrogen concentration $(N)$ of the whole plant:

$f(N)=\frac{N-n_{\min }}{n_{\text {crit }}-n_{\text {min }}}$

where $n_{\min }$ is the minimum internal nitrogen quota, and $n_{\text {crit }}$ is the critical internal nitrogen quota. $f(N)$ is unity when the nitrogen concentration of the P. oceanica equals its critical value and decreases linearly to zero as $N$ decreases to the minimum nitrogen concentration.

The shading effect is not introduced in this version of the model. But this factor can be related to space limitation mechanism $(S)$ to control the carrying capacity of the system. Epiphytes reduce the surface available for photosynthesis in P. oceanica leaves, and are thus responsible for direct shading. The increase in space limitation parallels an increase in leaf shading by epiphytes. Similarly, self-shading increases as a consequent of the increase in space limitation for leaves. This effect also indirectly controls the rhizome and root compartments that is related to the above-ground biomass though the translocation process. A space limitation effect has been proposed in other models for above- and below-ground biomass (Verhagen and Nienhuis, 1983). The present model assumes a spatial limitation for epiphytes also.

$f(S)=1-\exp \left[-\left(\frac{L-\mathrm{sl}}{\mathrm{ksl}}\right)^{2}\right]$

where $\mathrm{sl}$ is the maximum leaf biomass, and ksl is the leaf growth dependence on the space availability. The same equation was used for the below-ground biomass and the epiphytes. sr and se were the maximum biomass with the associated ksr and kse growth dependence on the space availability for roots and epiphytes, respectively.

Libes and Boudouresque (1987) reported the ability of $P$. oceanica to transfer organic compounds between leaves, roots and rhizomes. In the model used here, only transport from below- to above-ground material is considered. The formulation used assumes that transport is proportional to below-ground biomass uptake rate by means of translocation coefficient $k_{\text {trans }}$ estimated by model calibration.

transr $=k_{\text {trans }} \times$ Gror

For the translocation from leaves to epiphytes we made a major simplification, considering that part of the nutrients released by leaves are immediately consumed by epiphytes.

The mechanism causing senescence in seagrass, and the factor or factors-controlling dehiscence of old leaves are processes of major importance. The loss of leaf biomass can occur by the action of herbivory and hydrodynamism causing leaf breakage, however, these two factors can prevent retranslocation of nutrients (internal recycling) (Romero et al., 1998). From differences found in nitrogen concentrations between living and dead tissue. Mateo and Romero (1997) suggested that important nutrient recycling (50-70\%) may be due either to reclamation or to leaching after plant death (Hemminga et al., 1991; Kraemer et al., 1997). According to this important nitrogen economy developed by $P$. oceanica, which decreases the loss of nutrients, we considered respiration as the only permanent mechanism of loss, which is modelled as temperature dependent. The general forms of the 
respiration terms used for leaf, root and epiphytes were as follow:

Resl $=\operatorname{resl} \times f(T)$

where resl is the maximum leaf respiration rate. The same equation was used for below-ground biomass and epiphytes, with resr and rese the below-ground biomass and epiphytes maximum respiration rate, respectively.

The previous studies suggest that both below-ground biomass and leaves play a role in the $N$ nutrition of seagrasses (Alcoverro et al., 2000). We consider one compartment for leaves and below-ground biomass internal nitrogen quota.

$\frac{\mathrm{d} N}{\mathrm{~d} t}=\mathrm{Upt}-$ Grol $\times N-$ Gror $\times N$

Its balance is controlled by the uptake (Upt) from water and sediments, and by assimilation in new tissues.

$\mathrm{Upt}=(\mathrm{uptL}+\mathrm{uptR}) \times \mathrm{fb}$

uptL $=\operatorname{uptL}_{\mathrm{NH}_{4}}+\operatorname{uptL}_{\mathrm{NO}_{3}}$

Uptake of water ammonium (uptL $\mathrm{NH}_{4}$ ) and nitrate (uptL $\mathrm{NO}_{3}$ ) by leaves, and the uptake of sediment ammonium by below-ground biomass (uptR) will be assumed to occur in a Michaelis-Menten fashion:

$$
\begin{aligned}
& \text { uptL } \mathrm{NH}_{4}=\mathrm{Vml}_{\mathrm{NH}_{4}} \times \frac{\mathrm{NH}_{4 \mathrm{w}}}{\mathrm{NH}_{4 \mathrm{w}}+\mathrm{kl}_{\mathrm{NH}_{4}}} \\
& \text { uptL } \mathrm{NO}_{3}=\mathrm{Vml}_{\mathrm{NO}_{3}} \times \frac{\mathrm{NO}_{3 \mathrm{w}}}{\mathrm{NO}_{3 \mathrm{w}}+\mathrm{kl}_{\mathrm{NO}_{3}}} \\
& \text { uptR }=\mathrm{Vmr}_{\mathrm{NH}_{4}} \times \frac{\mathrm{NH}_{4 \mathrm{~s}}}{\mathrm{NH}_{4 \mathrm{~s}}+\mathrm{kr}_{\mathrm{NH}_{4}}}
\end{aligned}
$$

$\mathrm{Vml}_{\mathrm{NH}_{4}}, \mathrm{Vml}_{\mathrm{NO}_{3}}$ and $\mathrm{Vmr}_{\mathrm{NH}_{4}}$ represent a maximum mass-specific uptake rate for $\mathrm{NH}_{4 \mathrm{w}}$ and $\mathrm{NO}_{3 \mathrm{w}}$ by leaves, and $\mathrm{NH}_{4 \mathrm{~s}}$ for below-ground biomass, respectively with the associated Michaelis constants $\mathrm{kl}_{\mathrm{NH}_{4}}$, $\mathrm{kl}_{\mathrm{NO}_{3}}$ and $\mathrm{kr}_{\mathrm{NH}_{4}}$.

As usual in phytoplankton and macroalgae, to control the range of internal nitrogen, a feedback effect $(\mathrm{fb})$ is applied to the uptake function.

$\mathrm{fb}(N)=\frac{n_{\max }-N}{n_{\max }-n_{\min }}$

where $n_{\max }$ and $n_{\min }$ are the maximum and the minimum nitrogen quota.
The nutrient limitation used in epiphyte growth defined by Michaelis-Menten function:

$f(\mathrm{Ne})=\frac{\mathrm{NH}_{4 \mathrm{w}}+\mathrm{NO}_{3 \mathrm{w}}}{\mathrm{NH}_{4 \mathrm{w}}+\mathrm{NO}_{3 \mathrm{w}}+\mathrm{kn}}$

$f(\mathrm{Ne})$ is the epiphyte limitation coefficient by nitrogen and $\mathrm{kn}$ is the epiphyte half nitrogen saturation constant.

The values of the parameters have been set in the ranges reported in the literature. Some values are found from local laboratory or in situ experiments, and when no information was available the values were fixed by calibration within the literature range. The selected values of parameters used in this model are reported in Table 1. The system of differential equations has been implemented in Fortran and integrated with a Runge-Kutta fourth order routine with a daily time step.

\section{Results and discussion}

The versatility of the model allows to perform different simulation experiments. In this paper, part of the results are presented as an example of how insights can be derived from this model.

\subsection{Temperature and irradiance}

Fig. 2a shows the simulated and observed temperature values, considered the same at all depths. Fig. 2b gives the simulated and observed irradiance at the surface and at $10 \mathrm{~m}$ in the water column. The model also calculates the irradiance value at 20 and $30 \mathrm{~m}$ (not shown). Comparison of the model predictions with in situ measurements shows a good accordance.

\subsection{Leaves and epiphytes biomass}

Baseline leaf and epiphyte biomasses in the model were set to the approximate conditions in the Bay of Calvi during 1993 (Gobert et al., 1995). The maximum standing stocks for leaf biomass occurred in summer with 700,550 and $200 \mathrm{~g} \mathrm{DW} \mathrm{m}^{-2}$ for 10,20 and $30 \mathrm{~m}$, respectively (Fig. 3a). Maximum simulated epiphyte biomass was 160,95 and $40 \mathrm{~g} \mathrm{DW} \mathrm{m}^{-2}$ for 10, 20 and $30 \mathrm{~m}$, respectively (Fig. 3b). At $10 \mathrm{~m}$ leaf and epiphyte growth typically begins in April, peaks in 
Table 1

The parameters used in the $P$. oceanica growth model

\begin{tabular}{|c|c|c|c|c|}
\hline Name & Symbol & Value & Unit & Reference \\
\hline Leaf maximum specific growth rate & Groml & 0.012 & day $^{-1}$ & 1 \\
\hline Root maximum specific growth rate & Gromr & 0.0115 & day $^{-1}$ & 1 \\
\hline Epiphyte maximum specific growth rate & Grome & 0.065 & day $^{-1}$ & 1 \\
\hline Translocation rate from leaves to epiphytes & transl & 0.005 & day $^{-1}$ & 1 \\
\hline Water column light attenuation coefficient & $k_{\mathrm{z}}$ & 0.058 & $\mathrm{~m}^{-1}$ & 2 \\
\hline Irradiance half-saturation constant for leaf & kel & 225 & $\mu \mathrm{Em}^{-2} \mathrm{~s}^{-1}$ & 3 \\
\hline Irradiance half-saturation constant for epiphyte & Kee & 90 & $\mu \mathrm{Em}^{-2} \mathrm{~s}^{-1}$ & 3 \\
\hline Leaf optimal growth temperature & Toptl & 20 & ${ }^{\circ} \mathrm{C}$ & 4 \\
\hline Root optimal growth temperature & Toptr & 20 & ${ }^{\circ} \mathrm{C}$ & 4 \\
\hline Epiphyte optimal growth temperature & Topte & 15.5 & ${ }^{\circ} \mathrm{C}$ & 1 \\
\hline Leaf growth dependence on temperature & stl & 3.6 & ${ }^{\circ} \mathrm{C}$ & 5 \\
\hline Root growth dependence on temperature & str & 3.6 & ${ }^{\circ} \mathrm{C}$ & 5 \\
\hline Epiphytes growth dependence on temperature & ste & 2.6 & ${ }^{\circ} \mathrm{C}$ & 1 \\
\hline Posidonia minimum internal nitrogen quota & $n_{\min }$ & 4.28 & $\mathrm{mg} \mathrm{Ng}^{-1} \mathrm{DW}$ & 1 \\
\hline Posidonia critical internal nitrogen quota & $n_{\text {crit }}$ & 7.5 & $\operatorname{mg~N~g}{ }^{-1} \mathrm{DW}$ & 1 \\
\hline Maximum leaf biomass & sl & 750 & $\mathrm{~g} \mathrm{DW} \mathrm{m}^{-2}$ & 6 \\
\hline Maximum root biomass & $\mathrm{sr}$ & 3038 & $\mathrm{~g} \mathrm{DW} \mathrm{m}^{-2}$ & 7 \\
\hline Maximum epiphyte biomass & se & 225 & $\mathrm{~g} \mathrm{DW} \mathrm{m}^{-2}$ & 6 \\
\hline Leaf growth dependence on the space & ksl & 5 & $\mathrm{~g} \mathrm{DW} \mathrm{m}^{-2}$ & 5 \\
\hline Root growth dependence on the space & $\mathrm{ksr}$ & 3 & $\mathrm{~g} \mathrm{DW} \mathrm{m}^{-2}$ & 1 \\
\hline Epiphyte growth dependence on the space & kse & 2 & $\mathrm{~g} \mathrm{DW} \mathrm{m}^{-2}$ & 1 \\
\hline Means of translocation coefficient & $k_{\text {trans }}$ & 0.2 & day $^{-1}$ & 1 \\
\hline Leaf respiration rate & Resl & 0.0038 & day $^{-1}$ & 8 \\
\hline Root respiration rate & Resr & 0.0041 & day $^{-1}$ & 8 \\
\hline Epiphyte respiration rate & Rese & 0.0047 & day $^{-1}$ & 1 \\
\hline Leaf maximum specific uptake rate for $\mathrm{NH}_{4}$ & $\mathrm{Vml}_{\mathrm{NH}_{4}}$ & $0.2 \times 10^{-3}$ & $\mathrm{gNg}^{-1} \mathrm{Nh}^{-1}$ & 7 \\
\hline Leaf Michaelis constants for $\mathrm{NH}_{4}$ & $\mathrm{kl}_{\mathrm{NH}_{4}}$ & $0.021 \times 10^{-3}$ & $\mathrm{~g} \mathrm{~N}^{-1}$ & 7 \\
\hline Leaf maximum mass-specific uptake rate for $\mathrm{NO}_{3}$ & $\mathrm{Vml}_{\mathrm{NO}_{3}}$ & $0.2 \times 10^{-3}$ & $\mathrm{~g} \mathrm{Ng}^{-1} \mathrm{Nh}^{-1}$ & 7 \\
\hline Leaf Michaelis constants for $\mathrm{NO}_{3}$ & $\mathrm{kl}_{\mathrm{NO}_{3}}$ & $0.0301 \times 10^{-3}$ & $\mathrm{~g} \mathrm{N1}^{-1}$ & 7 \\
\hline Root maximum mass-specific uptake rate for $\mathrm{NH}_{4}$ & $\mathrm{Vmr}_{\mathrm{NH}_{4}}$ & $1.3 \times 10^{-3}$ & $\mathrm{~g} \mathrm{Ng}^{-1} \mathrm{Nh}^{-1}$ & 7 \\
\hline Root Michaelis constants for $\mathrm{NH}_{4}$ & $\mathrm{kr}_{\mathrm{NH}_{4}}$ & $0.149 \times 10^{-3}$ & $\mathrm{~g} \mathrm{~N}^{-1}$ & 7 \\
\hline Leaf maximum nitrogen quota & $n_{\max }$ & 11.003 & $\mathrm{mg} \mathrm{Ng}^{-1} \mathrm{DW}$ & 1 \\
\hline Epiphyte Michaelis constants for nitrogen & $\mathrm{kn}$ & 6.1 & $\mu \mathrm{M}$ & 1 \\
\hline
\end{tabular}

(1) Calibration; (2) Dauby (1985); (3) Madden and Kemp (1996); (4) Bulthuis (1987); (5) Bocci et al. (1997); (6) Gobert (1993); (7) Lepoint (2001); (8) Marsh et al. (1986).

June, and declines from early July. The biomass at 20 and $30 \mathrm{~m}$ diminished compared to $10 \mathrm{~m}$, and the peak for each variable occurred approximately 1 month and 1.5 months later, respectively than the peaking time at $10 \mathrm{~m}$. This suggests that the relative importance of biomass changes not only temporally but also as a function of depth within the community. The decrease of biomass according to depth is correlated with the low Leaf Area Index (LAI) (Gobert, 1993; Zupo et al., 1997), the low light compensation point, and high ratio of above- to below-ground biomass in deep water. The magnitude and the timing of epiphyte (except in 1993 at $10 \mathrm{~m}$ ) and leaf biomass peak in the model closely reproduced field measurements (Fig. 3a and b). In baseline runs, simulated dynamics for leaves and epiphyte biomass corresponded well with the data from the three depths $(10,20$ and $30 \mathrm{~m})$.

The values of the leaves biomasses of 1993 are comparable with those of 1997, 1998 and 1999 (Lepoint, 2001). And the model reproduce well the leaves biomass in 1975 and 1976 (Bay, 1984) (Fig. 4). In general, the leaf biomass is comparable with the literature data of other Mediterranean areas (Duarte and Chiscano, 1999). However, it should be noted that it is the density rather than the biomass, which informs about the health of the bed.

The epiphyte biomasses are also comparable with those of 1997-1999 (Lepoint et al., 1999). This is 

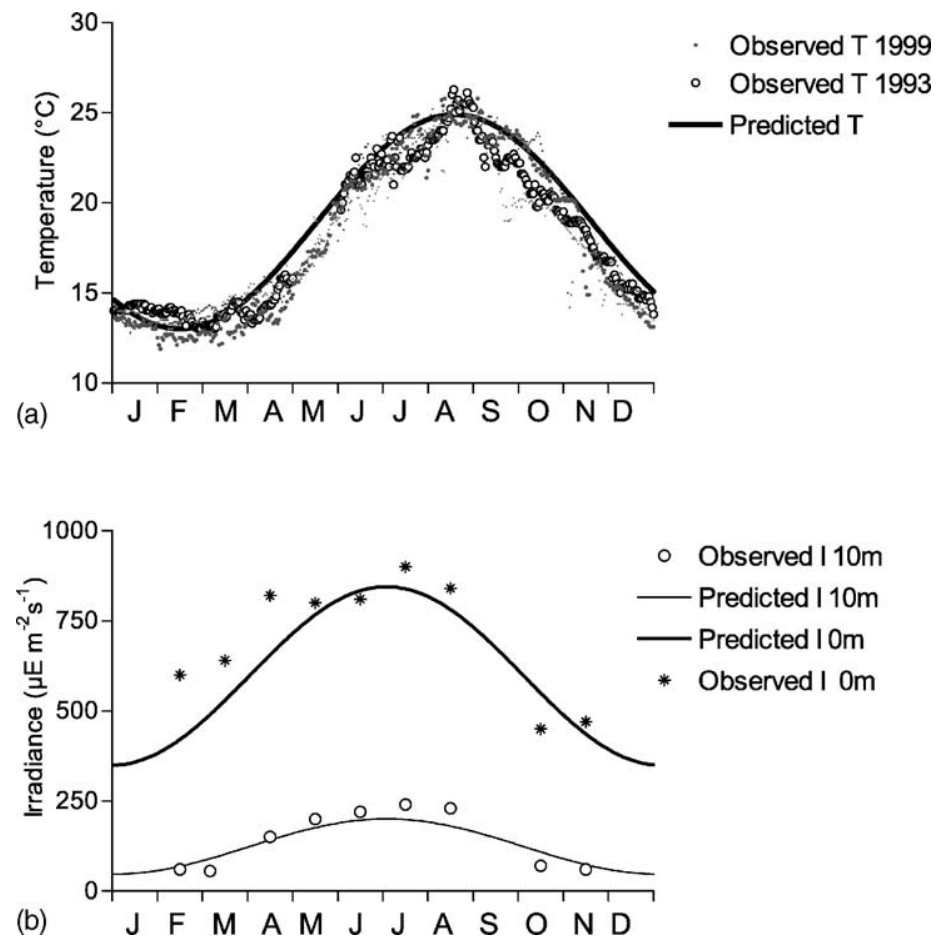

Fig. 2. Simulated and observed values of temperature (a) and irradiance (b).
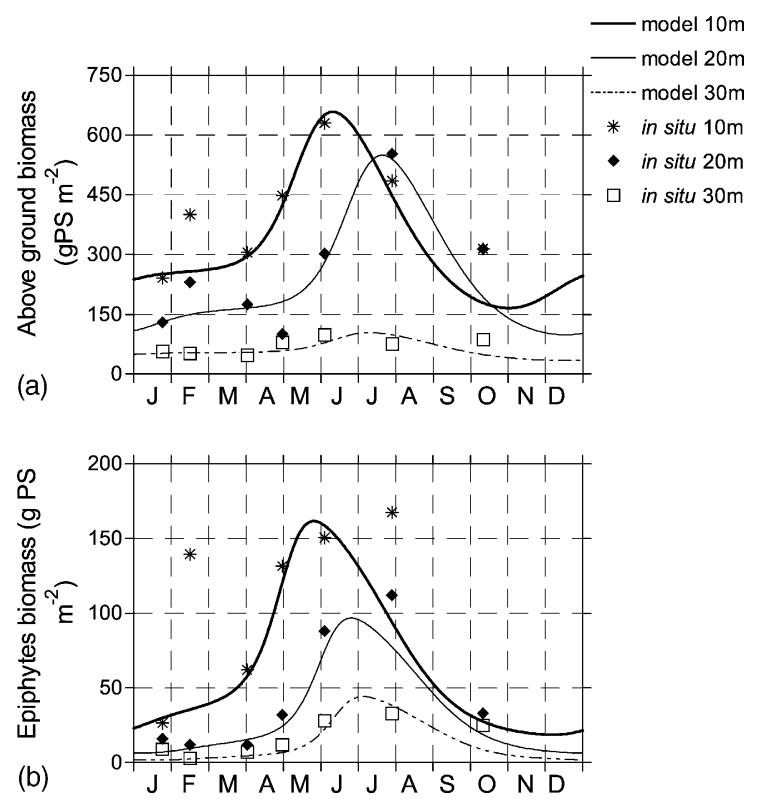

Fig. 3. Simulated (lines) and measured values of 1993 (points) for leaves (a), epiphytes (b) biomass at 10, 20 and $30 \mathrm{~m}$, respectively. consistent with measurements in other Mediterranean zones (Mazzella and Ott, 1984; Alcoverro et al., 1997a; Modigh et al., 1998), which is in agreement with the leaf biomasses.

The Fig. 5 presents the relationship between the observed and the simulated data. The correlation between the measured and simulated of leaf and epiphyte biomass values is in general good except for $30 \mathrm{~m}$ which is low and can be attributed to the influence of other so far unconsidered biological and environmental factors. This difference can also be explained by the fact that the model is more adapted for shallower depth, since the parameters are in general measured at low depths. Even if measurements are performed for each depth, the accuracy of the measured parameters would probably decrease with depth, due to the difficulty involved in sample collection and manipulation in deep water.

Fig. 6 presents the contribution of the epiphytes biomass to the total above-ground biomass. At 10, 20 and $30 \mathrm{~m}$ this contribution varies during the year with minima of 10,5 and $5 \%$ and the maxima ones of 

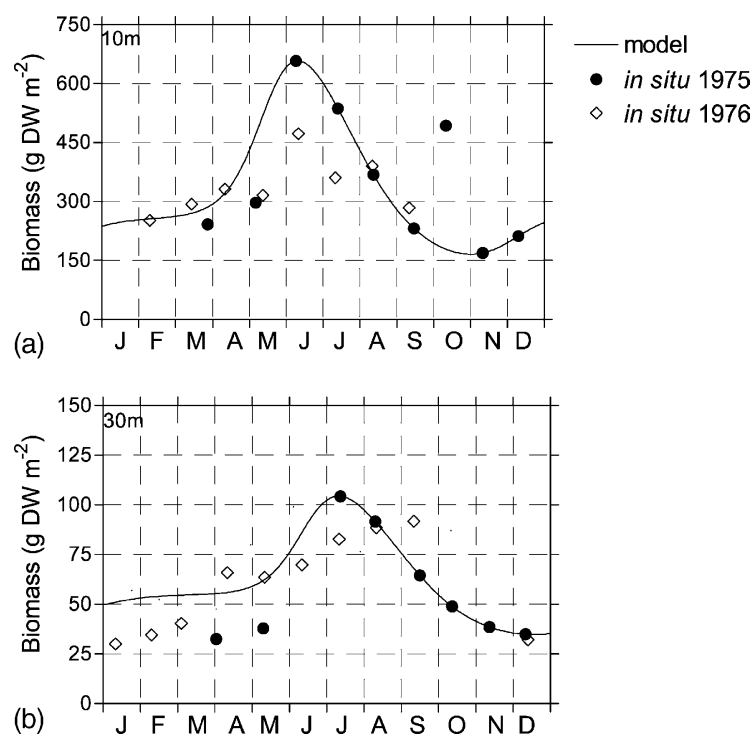

Fig. 4. Simulated (lines) and measured leaf biomass values of 1975 and 1976 (points) at $10 \mathrm{~m}$ (a) and $30 \mathrm{~m} \mathrm{(b).}$

25, 25 and 30\%, respectively. Belkhiria (1992) reports that the epiphytes biomasses measured at $10 \mathrm{~m}$ in the Bay of Calvi contribute with $5 \%$ in winter to the total above-ground biomass and more than $25 \%$ in summer. Gobert (1993), in the same bed, indicated contributions of $10 \%$ in winter and $25 \%$ in summer which are in conformity with our simulations. These values indicate that the epiphytic community is characterised by an important contribution to the biomass of the Posidonia beds. In other areas, the estimated value of epiphytes contribution to above-ground biomass, is more variable, from 18 to $56 \%$ for the various seagrass bed (Mesureur, 1981).

Light is, of course an important factor for any plant, but this study demonstrated once again that Posidonia is such a stable and auto regulating plant that it is able to overcome the simple relationship between light and growth. The chloroplasts in $P$. oceanica leaves are densely packed in the monolayered epidermis and are able to collect light immediately at the leaf surface. This represents the adaptation of $P$. oceanica to the aquatic environment and low light conditions (Mariani-Colombo et al., 1983), as opposed to terrestrial plants. It stores the product of photosynthesis in a manner not allowing the immediate identification of the photosynthesis in terms of leaf elongation.
However, given the relationship between temperature and light, this type of model may be an alternative to the temperature one: while the real peaks of production cannot be seen, but the average yearly production may be calculated using an alternative system.

\subsection{Below-ground biomass}

For the below ground biomass there are less measurements than the leave one. We, therefore, limited the simulation to the below ground biomass at $10 \mathrm{~m}$ because we haven't measurements at 20 and $30 \mathrm{~m}$. The simulation at $10 \mathrm{~m}$ (Fig. 7) indicated that the below-ground biomass shows very small seasonal changes (around $3000 \mathrm{~g} \mathrm{DW} \mathrm{m}^{-2}$ ), in contrast to the above-ground biomass, which is confirmed by Lepoint (2001). The below-ground biomass simulated in this work can constitute up to the double of those evoked for other areas (Duarte and Chiscano, 1999). The fact that the below-ground biomasses in this work are higher constitutes an essential ecological aspect of the Posidonia of the Bay of Calvi, because they play a paramount role in the incorporation of the nutrients necessary to the plant (Touchette and Burkholder, 2000). The weak nutrient concentration in the sediment pore water of the Bay of Calvi compared to the other areas (Lepoint, 2001), is correlated with the importance of the below-ground biomass. This importance constitutes an advantage in the oligotrophic zone making it possible to benefit from the sediments nutrients, inaccessible to the other producers (Hemminga, 1998).

P. oceanica, like the seagrasses species of the genera Amphibolis and Phyllospadix, tends to develop very high above-ground (about $500 \mathrm{~g} \mathrm{DW} \mathrm{m}^{-2}$ or higher) biomass. On the other hand, below-ground biomass developed by Posidonia exceeds by far (about $1000 \mathrm{~g} \mathrm{DW} \mathrm{m}^{-2}$ or higher) those developed by other seagrasses (Duarte and Chiscano, 1999). Other species of the genera Zostera, Halophila and Halodle, are particularly characterised by a high biomass of the above-ground relative to the below-ground biomass (Duarte and Chiscano, 1999).

The $P$. oceanica average simulated ratio of belowto above-ground biomass vary between 4.5 and 19.3. The minimal value correspond to the experimental one proposed by Lepoint et al. (in press), which 

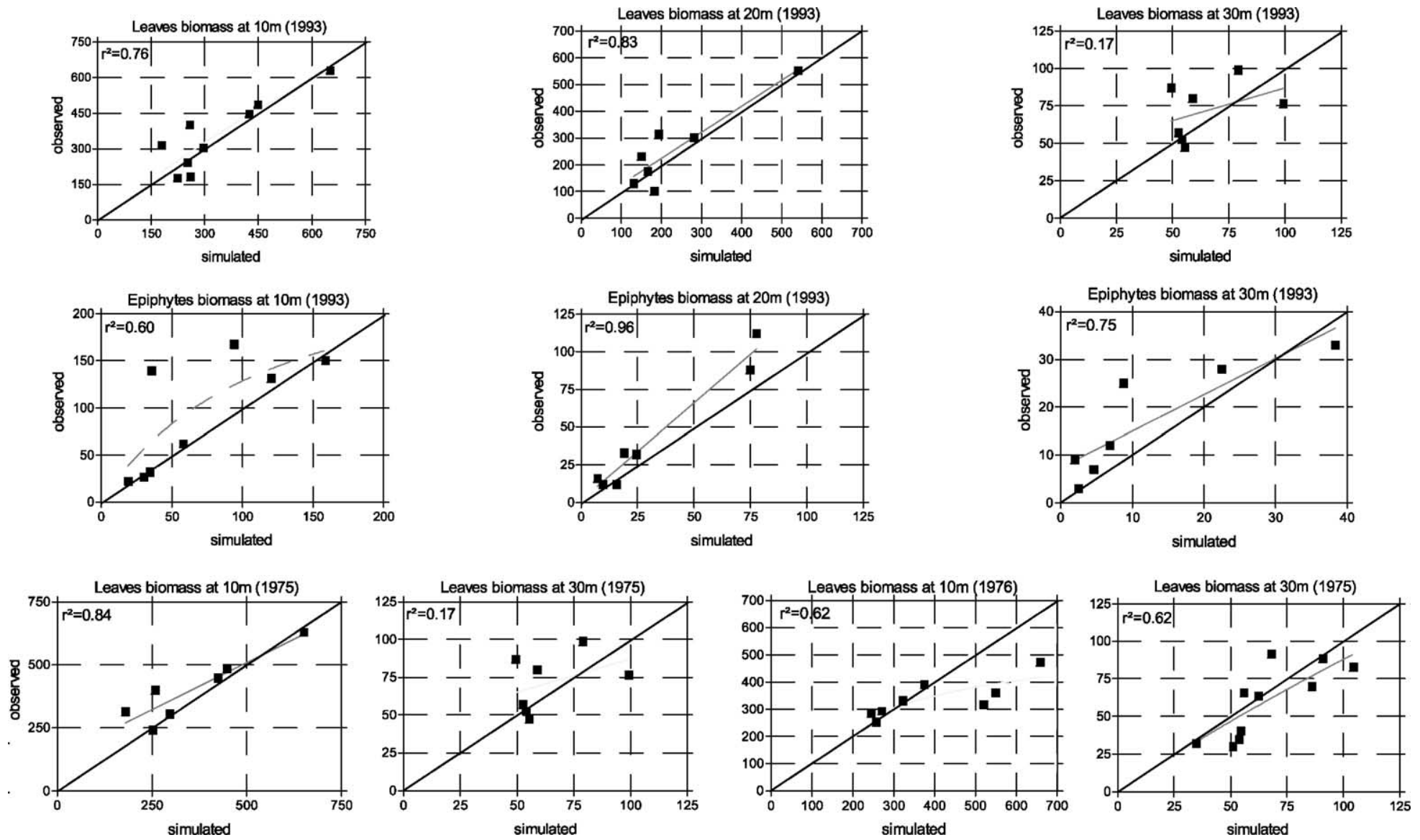

Fig. 5. Leaves and epiphytes biomass $\left(\mathrm{g} \mathrm{DW} \mathrm{m}^{-2}\right)$ observed vs. simulated data. 

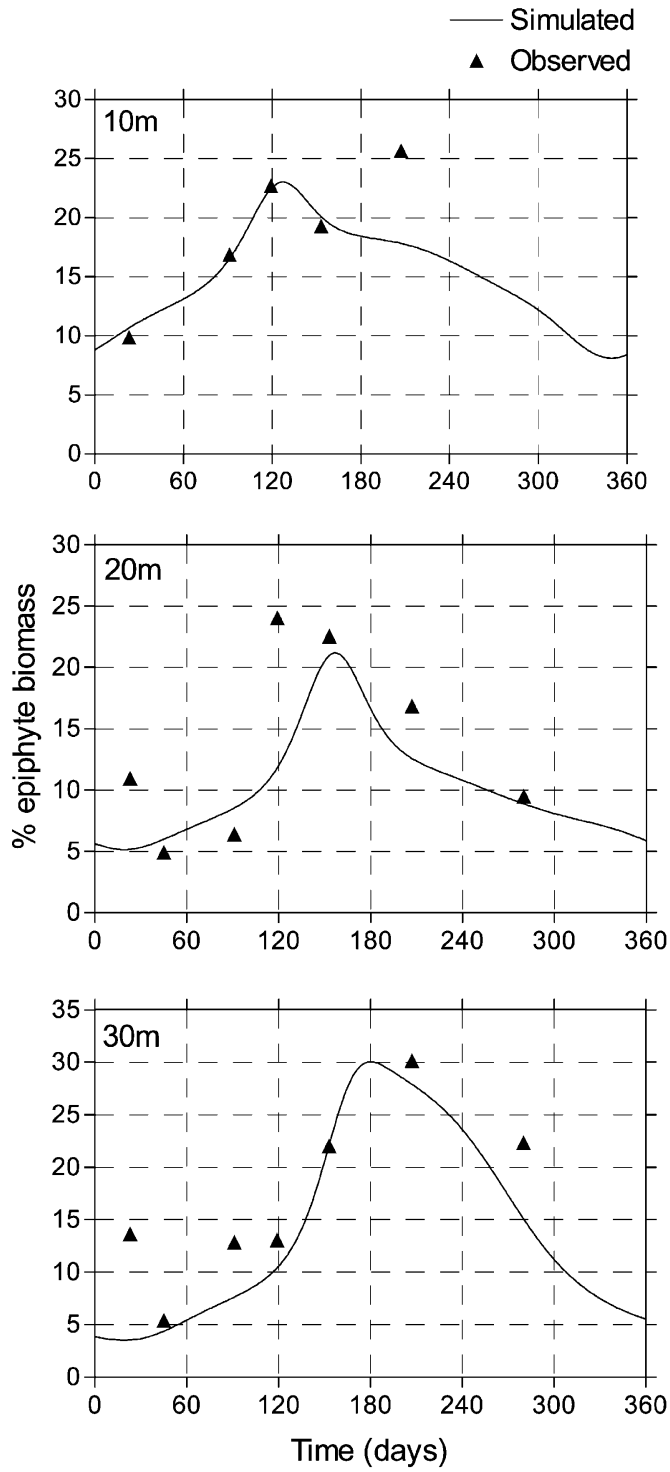

Fig. 6. Simulated (line) and measured values (points) of the percentage contributions of the contribution of the epiphytes biomass to the above-ground biomass.

was calculated with maximal value of above-ground biomass. The massive below-ground biomass can play a major role in nutrient economy by means of storage and retranslocation (Alcoverro et al., 1997b). The decrease of the below-ground biomass with depth is related to the decrease in that above-ground biomass. Therefore, there is a significant tendency for the ratio

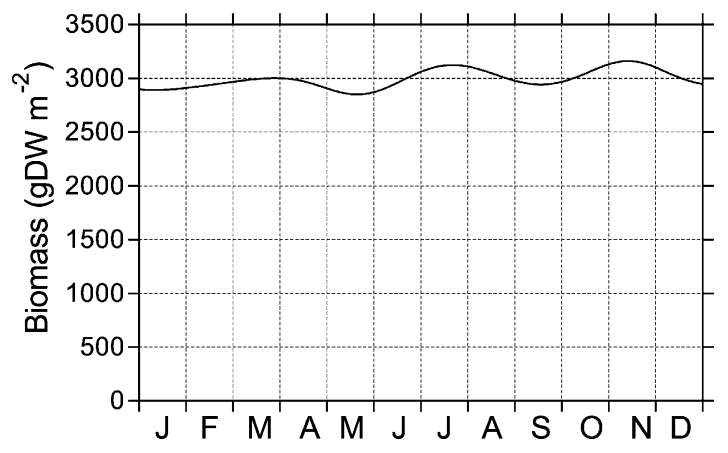

Fig. 7. Simulated values of the Posidonia below-ground biomass.

of above-ground to below-ground biomass to decline with increasing depth.

\subsection{Internal nitrogen concentration}

The simulation of the annual evolution of the internal nitrogen concentration presents (Fig. 8) a good fit with measurements of 1997 (Lepoint, 2001), which is characterised by a weak variation during the year. As far as the importance of the below-ground biomass is concerned more than $50 \%$ of internal nitrogen that is contained in the plant is in this compartment, therefore it is not surprising that the evolution of the internal nitrogen follows the below-ground biomass. It is important to indicate that the internal nitrogen concentration is characterised by a slow variation, which can be related to the capacity of the posidonie to use several strategies to satisfy his nutrients need (e.g. take the nutrients by different parts of the plant, nutrients reclamation from dead leaves...).

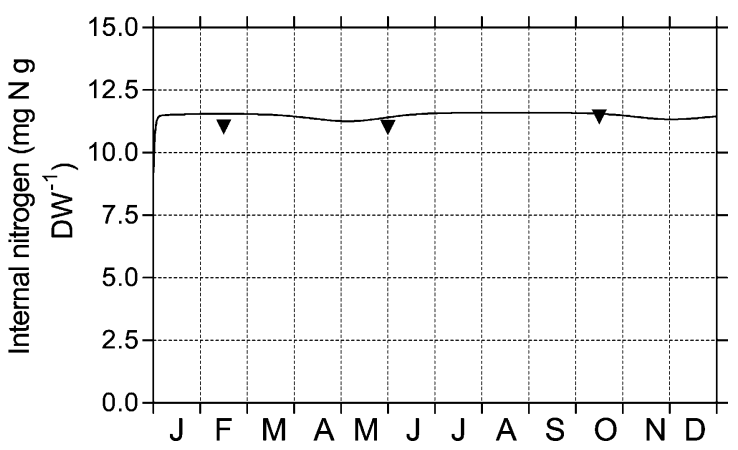

Fig. 8. Simulated (line) and measured value (points) of the Posidonia internal nitrogen quota. 


\subsection{Above- and below-ground production}

In our knowledge for all seagrasses the aboveand below-ground productions were estimated in a small fraction as the below-ground biomass. To determine the production of above-ground we used the relationships (Eq. (20)) between the production and biomass proposed by Duarte and Chiscano (1999). For below-ground production data were estimated using a relationship between above- and below-ground productions (Eq. (21))

\section{Above-ground production}

$$
=0.1 \times \text { above-ground biomass }(0.64 \pm 0.06)
$$

Above-ground production

$$
=2.81 \times \text { below-ground production }{ }^{(0.5 \pm 0.07)}
$$

In the relationships (20) and (21) the values used for the power is 0.64 and 0.5 , respectively. These relationships were derived from 30 species of seagrass (including $P$. oceanica), which represent more than half of the global seagrass species.

In our model, we observed that the production reaches a maximum of $2.45,1.54$ and $0.41 \mathrm{~g} \mathrm{DW} \mathrm{m}^{-2}$ day $^{-1}$ for above-ground, and $0.29,0.28$ and $0.268 \mathrm{~g}$ DW m ${ }^{-2}$ day $^{-1}$ at 10,20 and $30 \mathrm{~m}$, respectively. The average production rate calculated over a 12-month period: $1.59,0.90$ and $0.29 \mathrm{~g} \mathrm{DW} \mathrm{m}^{-2}$ day $^{-1}$ for above-ground and $0.28,0.27$ and $0.264 \mathrm{~g} \mathrm{DW} \mathrm{m}^{-2}$ day $^{-1}$ for below-ground at 10,20 and $30 \mathrm{~m}$, respectively. Bay (1984) has found in the of Bay of Calvi average values of the leaves production of 1.632 and $0.261 \mathrm{~g} \mathrm{DW} \mathrm{m}^{-2} \mathrm{~J}^{-1}$, respectively at 10 and $30 \mathrm{~m}$, which are comparable with values found in this work. The model showed that $84 \%$ of the P. oceanica total production may be contributed by the above-ground biomass. The production of shoot levels of deep-water $P$. oceanica meadows is lower than values obtained in shallow-water (Dalla Via et al., 1998). In fact, the shallow-water meadows are receiving higher levels of irradiance compared to the deep-water meadows. A reduction in shoot density caused a reduction in self-shading by $P$. oceanica leaves at the deep site, and light conditions within the stand became, therefore, similar at both sites (Dalla Via et al., 1998).

The relatively high production of these seagrass meadows is ecologically significant. However, the average biomass and primary production of phytoplankton is 9.2 and $0.35 \mathrm{~g} \mathrm{DW} \mathrm{m}^{-2}$ day $^{-1}$, respectively (Duarte and Chiscano, 1999). In particular, in the study area where the local water column primary production rate is very low (Goffart, 1992; Dauby and Bouquegneau, submitted).

A previous study (Romero et al., 1998) demonstrated that the rank of leaves in the shoot is important
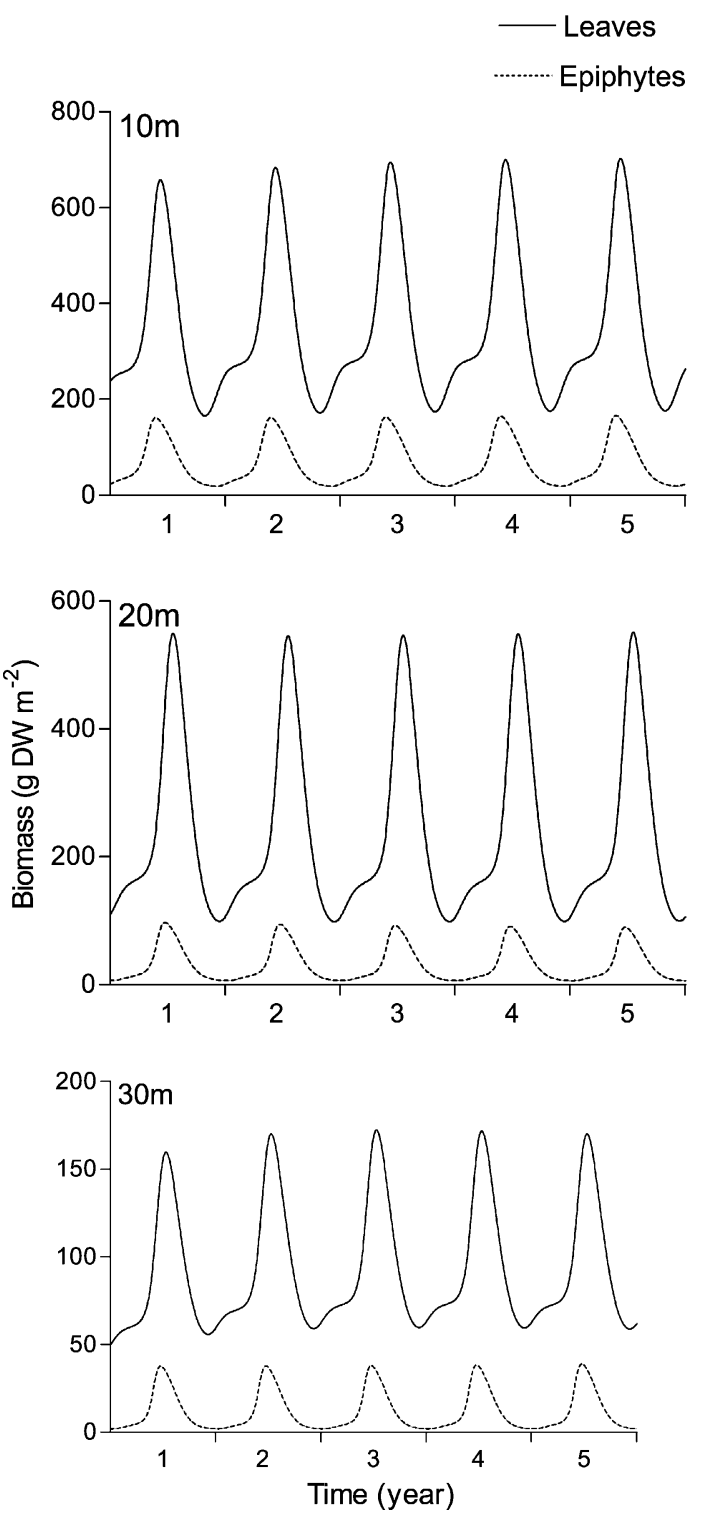

Fig. 9. Simulated epiphytes and leaves biomass for 5 years at 10 , 20 and $30 \mathrm{~m}$. 
for growth evaluation of $P$. oceanica. In fact, the youngest leaves showed the highest growth rates and, in particular, the growth of leaves of second and third rank is correlated to the growth of the whole shoot, regardless of depth (Kraemer et al., 1997; Zupo et al., 1997; Dauby and Bouquegneau, submitted). The density and leaf assemblage of the shoot (number of leaves by shoot, age of each leaf, etc.) can influence the growth mechanism. Therefore, environmental factors influence $P$. oceanica growth dynamics, although internal mechanisms regulate growth as demonstrated previously (Ott, 1979).

When expressed as relative growth rate (by dividing production by biomass), the value of growth rate was $47 \times 10^{-4} \mathrm{day}^{-1}$ for above ground and $1.21 \times$ $10^{-4}$ day $^{-1}$ for below ground. Thus, the growth rate is more important for leaf than for below ground.

In $P$. oceanica the turn-over of above-ground tissue is faster than that of below-ground tissue. The rela- tively slower turnover of the below-ground organs of seagrasses indicates a greater capacity for the longterm accumulation of material. At the greater depths, lower irradiance levels are likely to result in lower production levels, hence a slower turn-over. This capacity can be explained by the long-lived seagrass $P$. oceanica compared to other species (Romero et al., 1994). The much slower turn-over of $P$. oceanica in comparison to other species is indicative of the climax species (Erftemeijer and Stapel, 1999), while the higher turn-over is indicative of the opportunistic species.

\subsection{Long-term simulation}

Since annual predictions agreed with available data, analyses of long-term stability can be done with temporal discrepancy. Using the same values of parameters, initial conditions and forcing functions as the first model, a long-term simulation (over 5 years) was
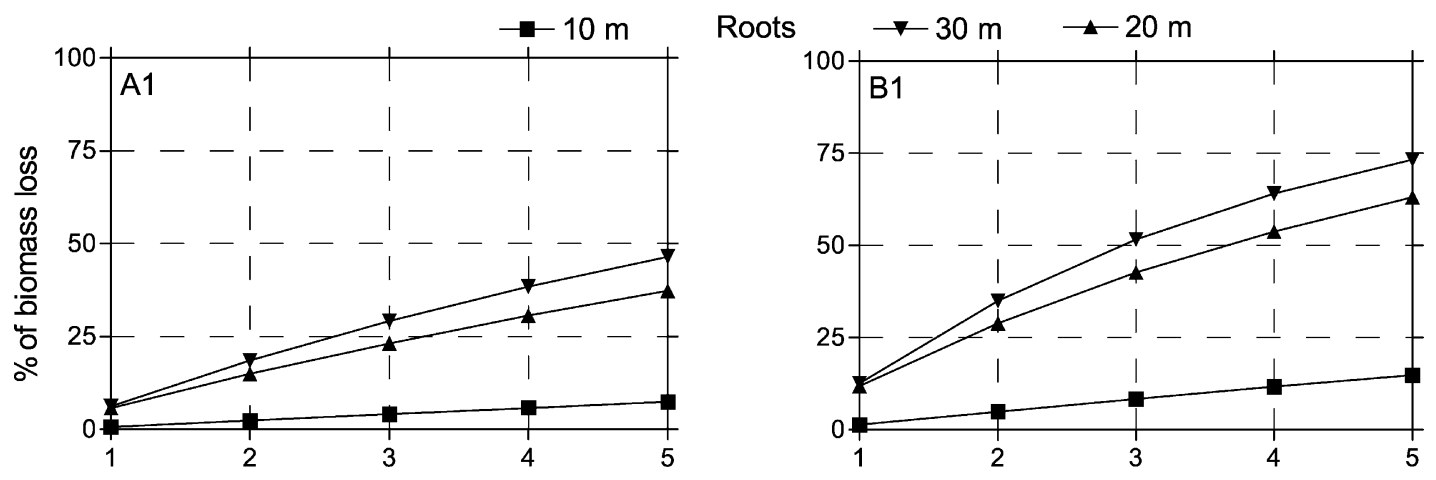

\section{Leaves}
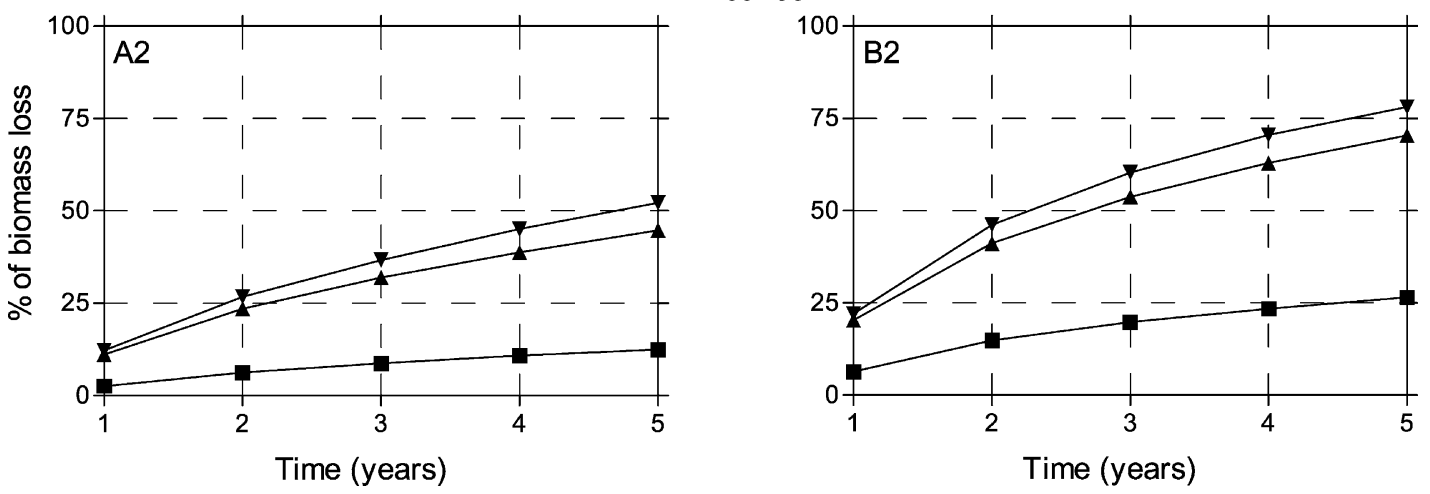

Fig. 10. Calculated percent of biomass loss as a function of water depth and time for $10 \%$ (A) and $20 \%$ (B) augmentation of extinction coefficient. 
performed. The analysis of these results (Fig. 9) shows a conservation of the leaves, and epiphytes biomass at each depth for the 5 years, though in reality, biomass varies between years. The invariability in the model can be explained by the fact that temperature, light and initial conditions were the same for all years. Therefore, to study the evolution of the different variables over a long period, it is necessary to have a good representation of the variability of the forcing variables and of the initial conditions.

\subsection{Change in the water irradiance}

Several studies confirmed the evident long-term decrease of seagrass biomass in general (Short and Neckles, 1999) and of $P$. oceanica in particular (Pergent et al., 1994; Marba et al., 1996; Ruiz and Romero, 2001). The reduction in the light which reaches the bottom may be one of the main factors responsible for the biomass decrease (Hemminga, 1998). Submarine irradiance (as photosynthetically active radiation or PAR) is attenuated with depth in the water column due to absorption, and scattering by water itself, dissolved organic compounds, and suspended particles. The suspended particles concentration is by far the most important factor and variable parameter affecting irradiance attenuation of light in several bays in the coastal NW Mediterranean (Dauby et al., 1995; Duarte et al., 1998). The shading effect is a combination of the actual concentration of suspended particles and of the variation of this concentration in time.

We performed several simulations in order to evaluate the influence of light intensity changes which can be related to one or some of the factors indicated before. To this aim, we created an artificial disturbance by increasing the attenuation coefficient by 10 and $20 \%$. Then, we evaluated at each depth the percentage of mean annual biomass, losses for above- and below-ground biomass which is compared to the reference state. The percentage of the biomass loss increases with time and depth, according to the disturbance augmentation and according to the variables. Below-ground biomass loss varied between $1 \%$ (Fig. 10A1) in the first year for the $10 \%$ disturbance and $73 \%$ for the $20 \%$ disturbance (Fig. 10B1) in the fifth year. Leaf biomass loss varied between $3 \%$ (Fig. 10A2) in the first year for the $10 \%$ disturbance and the loss reached 78\% (Fig. 10B2) for the
$20 \%$ disturbance for the fifth year. We noticed that the loss of leaf biomass is higher than losses in the below-ground biomass. The impact of light perturbation is less important in the below-ground biomasses. However, few studies have examined the cascade effects of light reduction involved in the below-ground organs of seagrasses (Hemminga, 1998).

(a)
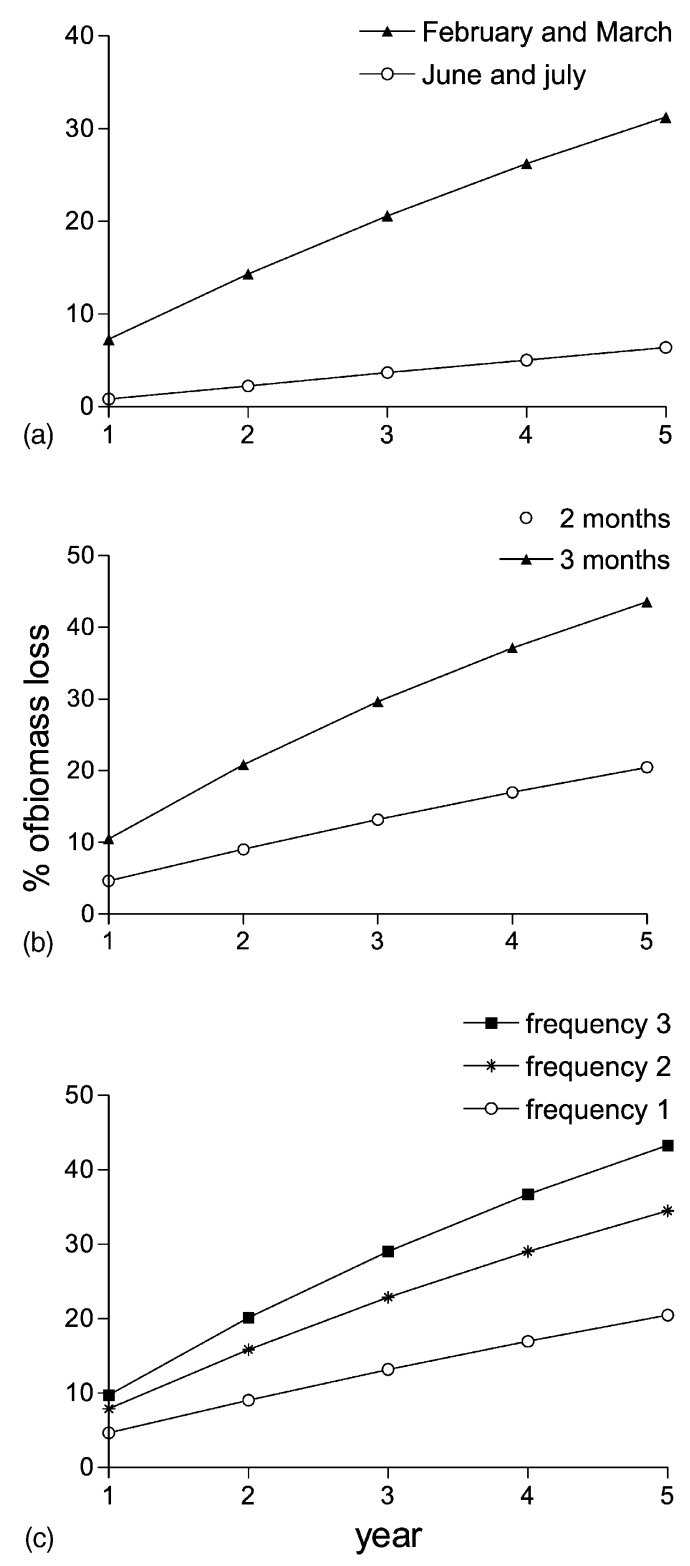

Fig. 11. Percent of epiphytes biomass loss for different scenario period (a), duration (b) and frequency (c) of the perturbation. 
To show the relative importance of period, frequency and duration of the attenuation of light we analysed the biomass of epiphytes at $10 \mathrm{~m}$. To test the importance related to the period of the disturbance, we have applied the same increase $(20 \%)$ in the attenuation coefficient at different periods. First at the beginning of the year (February and March) and subsequently during June and July. Fig. 10A shows that the mean annual biomass loss during the first period of disturbance is about $31 \%$ in the fifth year, which is higher than the loss in the second case $(6 \%)$. This can be explained by the fact that at the beginning of the year $P$. oceanica assimilates nitrogen necessary for growth. Alcoverro et al. (1995) indicated that the $P$. oceanica tissue have high nutrient concentrations in winter which decline subsequently with increasing plant growth towards summer.

We tested two different durations of the disturbance, namely 2 and 3 months at the beginning of the year with the same increase (20\%). We noticed that the biomass loss increased with increased duration with a loss of about 20 and $44 \%$, respectively, for the first and second durations (Fig. 11b). In a plant such as $P$. oceanica, with an economic complex growth mechanism a short-term perturbation does not suffice to induce a significant loss.

We have also tested the importance of the frequency of the disturbance, using one, two and three times the same perturbation (20\%). The losses are about 20, 35 and $43 \%$, respectively (Fig. 11c). Thus, the simula- tion model indicates that losses in biomass positively correlate with frequency. Our results are consistent with those of Bach et al. (1997) which have already shown experimentally and by model in a Z marina bed the importance of time, duration, intensity and frequency of the augmentation of the attenuation coefficients. The simulations indicated extreme sensitivity to changes in the average water column light attenuation. We can conclude that it is possible that gradual changes in these factors over the past decades be partially or totally responsible for the recent reduction in the P. oceanica in the Bay of Calvi and in other Mediterranean zones.

\subsection{Sensitivity analysis}

A sensitivity analysis of most parameters was done to investigate their influence on the state variables of the model. Sensitivity has been computed as (Chapelle et al., 2000):

Sens $=\frac{1}{n} \sum_{i=1}^{n} \frac{|Y-\mathrm{Yx}|}{Y}$

where $Y$ is the state variable at the standard run, $\mathrm{Yx}$ is the new variable value corresponding to the new parameter value, $n$ is the simulated number of days (365).

To obtain an indication of the sensitivity of the model results to the parameters, setting we

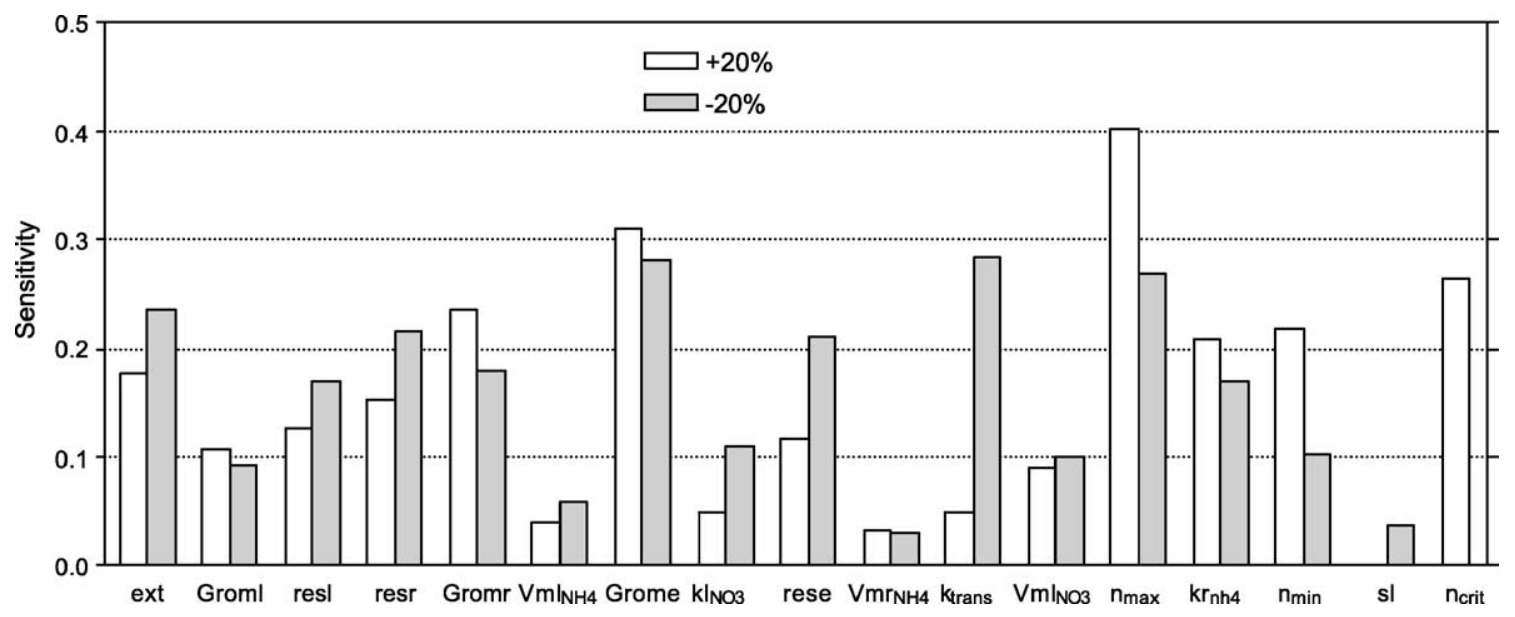

Fig. 12. Sensitivity analysis results of parameters. 
subsequently increased and decreased each of the main model parameters by $20 \%$. Only important sensitivity of the above-ground, below-ground and epiphyte biomass for each parameter is represented in the Fig. 12. The model results are considerably sensitive (Sens greater than 0.25 ) to variation in the following parameters: ext, Grome, $k_{\text {trans }}, n_{\max }$ and $n_{\text {crit }}$. Other parameters such as $\mathrm{Vml}_{\mathrm{NH}_{4}}, \mathrm{kl}_{\mathrm{NO}_{3}}, \mathrm{Vmr}_{\mathrm{NH}_{4}}$ and sl have only minor effects on the results.

This sensitivity can be explained by the major hypothesis assumed in this model for constant values for biological parameters. Normally, in ecosystems, rates of biological processes are not constant in time and with depth. However, the modeller has, in general only the possibility of choosing some mean values for the parameters. It may be a better approach to make a model with a flexible set of parameters, or at least have a specific parameter for each range of depth $(10,20$ and $30 \mathrm{~m})$. In this ecological model, it is not possible to reflect every detail of the system, and it is only desirable to simulate whole system characteristics. Experimental data restricting parameter uncertainty would give an important quality improvement to this simulation. Thus, particular care must be taken when selecting these coefficients.

\section{Conclusion}

In this study, the first steps to model $P$. oceanica growth and production in the Bay of Calvi have been developed. These processes are governed by environmental factors such as temperature and irradiance. For the investigated Bay of Calvi area it seems reasonable to conclude that the model includes the most important factors controlling seagrass growth.

The available field data showed that this model provides a reasonable representation of the seasonal cycle, at least during the period when samples are available. The completion of a seasonal sampling program will allow a more complete analysis. The model indicated successfully the long-term evolution and the effect of shading on the growth. The artificial shading experiments with seagrass clearly demonstrated the importance of reduced light conditions on the density decrease. In the Bay of Calvi, we calculated that minimum light requirements of $P$. oceanica growth, is $15.7 \%$, of surface irradiance, value which in accordance with the values (between 10 and 16\%) proposed by Ruiz and Romero (2001).

This model confirm that $P$. oceanica reacts rapidly to external perturbation in the Mediterranean Sea, which are driven by climatic change (Goffart et al., in press). Due to their sensitivity to shading, seagrasses can be selected as key organisms for feedback monitoring systems. Leaf, below-ground biomass and epiphyte biomass can be chosen as response variables. This work supports the view that simulations can be a powerful tool to develop theoretical frameworks for understanding $P$. oceanica dynamics.

The model indicated also where data were lacking, thereby suggesting directions for future research. For example, better understanding of the internal nitrogen quota of the whole plant and of the nutrient translocation process between leaves and roots will lead to an increased understanding of $P$. oceanica dynamics.

This model considers a whole-plant approach. The dominance of below-ground tissues with respect to total seagrass biomass now is well recognised but seldom considered in physiological or ecological studies. Since below-ground biomass appears to play critical roles in the biogeochemical processes that occur in the sediments, as well as it regulate processes in the overlying water column, it is important to include this component in seagrass models.

This model will be further coupled with a phytoplankton model and other primary producers in order to simulate the competition between benthic and pelagic primary producers. It can be applied as a tool for simulating the effects of various changes in physical, chemical and biological interactions.

\section{Acknowledgements}

This research has been supported by "Communauté Française de Belgique" (A.R.C. 97/02.112) and the "Fonds National de la Recherche Scientifique" (FRFC 2.4570.97 and FRFC 2.4609.99). We thank Valerio Zupo, Mohamed Elmezgueldi, Hassan Badrane, and Sandi Toomey for their valuable comments. We thank also the anonymous reviewers for helpful comments. J.-H. Hecq is Research Associate of the Belgian National Fund for Scientific Research (FNRS). This is MARE publication MAREO13. 


\section{References}

Alcoverro, T., Duarte, C.M., Romero, J., 1995. Annual growth dynamics of Posidonia oceanica: contribution of large-scale versus local factors to seasonality. Mar. Ecol. Prog. Ser. 120, 203-210.

Alcoverro, T., Duarte, C.M., Romero, J., 1997a. The influence of herbivores on Posidonia oceanica epiphytes. Aquat. Bot. 56, 93-104.

Alcoverro, T., Romero, J., Duarte, C.M., Lopez, N.I., 1997b. Spatial and temporal variations in nutrient limitation of seagrass Posidonia oceanica growth in the NW Mediterranean. Mar. Ecol. Prog. Ser. 146, 155-161.

Alcoverro, T., Manzanera, M., Romero, J., 2000. Nutrient mass balance of the seagrass Posidonia oceanica (L.) Delile: the importance of nutrient retranslocation. Mar. Ecol. Prog. Ser. 194, 13-21.

Bach, H.K., 1993. A dynamic model describing the seasonal variations in growth and the distribution of eelgrass (Zostera marina L.) I. Model theory. Ecol. Model. 65, 31-50.

Bach, H.K., Jensen, K., Lyngby, J.J., 1997. Management of marine construction works using ecological modelling. Estuarine Coastal Shelf Sci. 44 (Suppl. A), 3-14.

Bay, D., 1984. A field study of the growth dynamics and productivity of Posidonia oceanica (L.) Dellile in Calvi Bay. Corsica. Aquat. Bot. 20, 43-64.

Belkhiria, S., 1992. Variation saisonnières et spéciation des différents stoks de carbone dans la frondaison de l'herbier de posidonie de la baie de la Revelata (Corse). Mémoire de licence. University of Liège, $56 \mathrm{pp}$.

Bocci, M., Coffaro, G., Bendoricchio, G., 1997. Modelling biomass and nutrient dynamics in eelgrass (Zostera marina L.): application to the lagoon of Venice (Italy) and Oresund (Denmark). Ecol. Model. 102, 67-80.

Borum, J., 1985. Development of epiphytic communities on eelgrass (Zostera marina) along a nutrient gradient in a Danish estuary. Mar. Biol. 87, 48-56.

Buia, M.C., Mazzella, L., 1991. Reproductive strategies of the Mediterranean seagrasses, Posidonia oceanica (L.) Delile, Cymodocea nodosa (Ucria) Aschers., and Zostera noltti Hornem. Aquat. Bot. 40, 343-362.

Bulthuis, D.A., 1987. Effect of temperature on photosynthesis and growth of seagrass. Aquat. Bot. 27, 27-40.

Chapelle, A., Ménesguen, A., Deslous-Paoli, J.M., Souchu, P., Mazouni, N., Vaquer, A., Millet, B., 2000. Modelling nitrogen, primary production and oxygen in a Mediterranean lagoon. Impact of oysters farming and inputs from the watershed. Ecol. Model. 127, 161-181.

Coffaro, G., Sfriso, A., 1997. Simulation model of Ulva rigidda growth in shallow water of the Lagoon of Venice. Ecol. Model. 102, 55-66.

Dalla Via, J., Sturmbauer, C., Schonweger, G., Sotz, E., Mathekowitsch, S., Stifter, M., Rieger, R., 1998. Light gradients and meadow structure in Posidonia oceanica, ecomorphological and functional correlates. Mar. Ecol. Prog. Ser. 163, 267-278.

Dauby, P., 1985. Dynamique et productivité de l'écosystème planctonique du golf de Calvi-Corse. Ph.D. thesis, University of Liège, 288 pp.
Dauby, P., Bouquegneau, J.M., submitted. Carbon uptake by seagrass bed producers. Mar. Ecol. Prog. Ser.

Dauby, P., Bale, A.J., Bloomer, N., Canon, C., Ling, D.R., Norro, A., Robertson, J.E., Simon, A., Théate, J.M., Watson, A.J., Frankignoulle, M., 1995. Particle fluxes over a Mediterranean seagrass bed: a one year case study. Mar. Ecol. Prog. Ser. 126, 233-246.

Dennison, W.C., Aller, R.C., Alberte, R.S., 1987. Sediment ammonium availability and eelgrass (Zostera marina) growth. Mar. Biol. 94, 469-477.

Duarte, C.M., 1990. Seagrass nutrient content. Mar. Ecol. Prog. Ser. 67, 201-207.

Duarte, C.M., 1991. Seagrass depth limits. Aquat. Bot. 40, 337363.

Duarte, C.M., Chiscano, C.L., 1999. Seagrass biomass and production: a reassessment. Aquat. Bot. 65, 159-174.

Duarte, C.M., Agusta, S., Satta, M.P., 1998. Partitioning particulate light absorption: a budget for a Mediterranean bay. Limnol. Oceanogr. 43 (2), 236-244.

Elkalay, K., Skliris, N., Frangoulis, C., Goffart, A., Gobert, S., Lepoint, G., Hecq, J.-H., 2000. A model describing the P. oceanica growth. Biol. Mar. Medit. 7 (2), 47-50.

Erftemeijer, P.L.A., Stapel, J., 1999. Primary production of deep-water Halophila ovalis meadows. Aquat. Bot. 65, 71-82.

Gobert, S., 1993. Hétérogénéité de la structure de l'herbier de posidonies de la baie de Calvi: variation à court et à long terme. Master in Oceanology, University of Liège, $50 \mathrm{pp}$.

Gobert, S., Belkhiria, S., Dauby, P., Havelange, S., Soullard, M., Bouquegneau, J.M., 1995. Variations temporelles de la phynologie et de la composition biochimique de la phanerogame marine Posidonia oceanica en Baie de Calvi. Bull. Soc. R. Sci. Liège 64 (4/5), 263-284.

Goffart, A., 1992. Influence des contraintes hydrodynamiques sur la structure des communautés phytoplanctoniques du bassin Liguro-Provençal (secteur Corse). Ph.D. thesis, University of Liège, $163 \mathrm{pp}$.

Goffart, A., Hecq, J.-H., Legendre, L., in press. Changes in the development of the winter-spring phytoplankton bloom in the Bay of Calvi (Northwestern Mediterranean) over the last two decades: a response to the changing climate? Mar. Ecol. Prog. Ser.

Harlin, M.M., Thorne-Miller, B., 1981. Nutrient enrichment of seagrass beds in Rhode Island coastal lagoon. Mar. Biol. 65, 221-229.

Hemminga, M.A., 1998. The root/rhizome system of seagrasses: an asset and a burden. J. Sea Res. 39, 183-196.

Hemminga, M.A., Harrison, P.G., van Lent, F., 1991. The balance of nutrient losses and gains in seagrass meadowa. Mar. Ecol. Prog. Ser. 71, 85-95.

Iizumi, H., Hattori, A., 1982. Growth and organic production of eelgrass (Zostera Marina L.) in temperature waters of the pacific coast of Japan. III. The kinetics of nitrogen uptake. Aquat. Bot. 12, 245-256.

Kraemer, G.P., Mazzella, L., Alberte, R.S., 1997. Nitrogen assimilation and partitioning in the mediterranean seagrass Posidonia oceanica. Mar. Ecol. 18 (2), 175-188.

Lepoint, G., 2001. Compétition pour l'azote inorganique entre le pelagos et le benthos d'un milieu côtier oligotrophe. Effets 
sur la dynamique de l'écosystème. Ph.D. thesis, University of Liège, 199 pp.

Lepoint, G., Havelange, S., Gobert, S., Bouquegneau, J.M., 1999. Fauna versus flora contirbution to the leaf epiphytes biomass in a Posidonia oceanica seagrass bed (Revellata Bay, Corsica). Hydrobiologia 394, 63-67.

Lepoint, G., Millet, S., Dauby, P., Gobert, S., Bouquegneau, J.M., in press. An annual nitrogen budget of seagrass Posidonia oceanica as determined by in situ uptake experiments. Mar. Ecol. Prog. Ser.

Libes, M., Boudouresque, C.F., 1987. Uptake and long-distance transport of carbon in the marine phanerogam Posidonia oceanica. Mar. Ecol. Prog. Ser. 38, 177-186.

Lorenti, M., Mazzella, L., Buia, M.C., 1995. Light limitation of Posidonia oceanica (L.) Delile leaves and epiphytes at different depths. Rapports Comm. Int. Mediterranean 34, 34.

Madden, C.J., Kemp, W.M., 1996. Ecosystem model of an estuarine submersed plant community, calibration an simulation of eutrophication responses. Estuaries 19 (2B), 457-474.

Marba, N., Duarte, C.M., Cebrian, J., Gallegos, M.E., Olesen, B., Sand-Jensens, K., 1996. Growth and population dynamics of Posidonia oceanica on the Spanish Mediterranean coast: elucidating seagrass decline. Mar. Ecol. Prog. Ser. 137, 203213.

Mariani-Colombo, P., Rascio, N., Cinelli, F., 1983. Posidonia oceanica (L.) Delile: a structural study of the photosynthetic apparatus. P.S.Z.N.I. Mar. Ecol. 4 (2), 133-145.

Mateo, M.A., Romero, J., 1997. Detritus dynamics in the seagrass Posidonia oceanica: elements for an ecosystem carbon and nutrient budget. Mar. Ecol. Prog. Ser. 151, 43-53.

Mazzella, L., Ott., J., 1984. Seasonal changes in some features of Posidonia oceanica (L.) Dellile leaves and epiphytes at different depths. In: Boudouresque, C.F., Grissac, A.J.D., Olivier, J. (Eds.), Proceedings of the International Workshop on Posidonia oceanica Beds. GIS Posidonie, Marseille, France, pp. 119-127.

Mazzella, L., Scipione, M.B., Buia, M.B., 1989. Spatio-temporel distribution of algal and animal communities in a Posidonia oceanica meadow. P.S.Z.N.I. Mar. Ecol. 10, 107-129.

Mazzella, L., Buia, M.C., Gambi, M.C., Lorenti, M., Russo, G.F., Scipione, M.B., Zupo, V., 1992. Plant-animal trophic relationships in the Posidonia oceanicaecosystem of the Mediterranean Sea: a review. In: John, D.M., Hawkins, S.J., Price, J.H. (Eds.), Plant-Animal Interactions in the Marine Benthos. Clarendon Press, Oxford, pp. 165-187.

Mesureur, B., 1981. Un aspect écologique de l'herbier de posidonies dans la baie de Calvi: productions primaire et primaire et secondaire de la couverture épiphytique. Mémoire de licence. University of Liège, Belgique, $55 \mathrm{pp}$.

Modigh, M., Lorenti, M., Mazzella, L., 1998. Carbon assimilation in Posidonia oceanica: biotic determinants. Bot. Mar. 41, 249256.

Oshima, Y., Kishi, M.J., Sugimoto, T., 1999. Evaluation of the nutrient budget in a seagrass bed. Ecol. Model. 115, 19-33.

Orth, R.J., 1977. Effect of nutrient enrichment on the growth of the eelgrass Zostera marina in the Chesapeake Bay, Virginia, USA. Mar. Biol. 44, 187-194.

Orth, R.J., Van Montfrans, J., 1984. Epiphytes-seagrass relationships with an emphasis on the role of micrograzing: a review. Aquat. Bot. 18, 43-69.
Ott, J.A., 1979. Persistence of a seasonal growth rhythm in Posidonia oceanica (L.) Delile under constant conditions of temperature and illumination. Mar. Biol. Lett. 1, 99-104.

Pergent, G., Romero, J., Pergent-Martini, M., Mateo, A., Boudouresque, C.F., 1994. Primary production, stocks and fluxes in the Mediterranean seagrass Posidonia oceanica. Mar. Ecol. Prog. Ser. 106, 139-146.

Pirc, H., 1985a. Seasonal aspects of photosynthesis in Posidonia oceanica: influence of depth, temperature and light intensity. Aquat. Bot. 26, 203-212.

Pirc, H., 1985b. Growth dynamics in Posidonia oceanica (L.) Delile. P.S.Z.N.I. Mar. Ecol. 6, 141-165.

Romero, J., Pérez, M., Mateo, M.A., Sala, E., 1994. The belowgroud organs of the Mediterranean seagrass Posidonia oceanica as a biogeochemical sink. Aquat. Bot. 47, 13-19.

Romero, J., Perez, M., Alcoverro, T., Mateo, M.A., Lizaso, J.L.S., 1998. Production ecology of Posidonia oceanica (L.) Dellile meadows in Nueva Tabarca marine reserve: growth, biomass and nutrient stocks along a bathymetric gradient. Oecol. Aquat. $11,111-121$.

Ruiz, J.M., Romero, J., 2001. Effects of in situ experimental shading on the Mediterranean seagrass Posidonia oceanica. Mar. Ecol. Prog. Ser. 215, 107-120.

Short, F.T., 1980. A simulation model of seagrass production system. In: Phillips, R.C., McRoy, C.P. (Eds.), Handbook of Seagrass Biology: An Ecosystem Perspective. Garland STPM Press, New York, pp. 275-295.

Short, F.T., Neckles, H.A., 1999. The effects of global climate change on seagrasses. Aquat. Bot. 63, 169-196.

Touchette, B.W., Burkholder, J.M., 2000. Review of nitrogen and phosphorus metabolism in seagrasses. J. Exp. Mar. Bio. Ecol. 250, 133-167.

Verhagen, J.H.G., Nienhuis, P.H., 1983. A simulation model of production, seasonal changes in biomass and distribution of eelgrass (Zostera marina) in lake Grevelingen. Mar. Ecol. Program. Ser. 10, 187-195.

Wetzel, R., Neckles, H.A., 1986. A model of Zostera marina L. photosynthesis and growth: simulated effects of the selected physical-chemical variables and biological interactions. Aquat. Bot. 26, 307-323.

Williams, S.L., Ruckelshaus, M.H., 1983. Effect of nitrogen availability in a natural and herbivory on eelgrass (Zosetera marina) and epiphytes. Ecology 74, 904-918.

Zimmerman, R.C., Smith, R.D., Alberte, R.S., 1987. Is growth of eelgrass nitrogen limited? A numerical simulation of the effect of light and nitrogen on the growth dynamics of Zostera marina. Mar. Ecol. Prog. Ser. 41, 167-176.

Zimmerman, R.C., Cabello-Pasini, A., Alberte, R.S., 1994. Modelling daily production of aquatic macrophytes from irradiance measurements: a comparative analysis. Mar. Ecol. Prog. Ser. 114, 185-196.

Zupo, V., Buia, M.C., Mazzella, L., 1997. A production model for Posidonia oceanica based on temperature. Estuarine Coastal Shelf Sci. 44, 483-492. 


\section{Further reading}

Bedhomme, A.L., Thelin, I., Boudouresque, C.F., 1983. Mesure de la production primaire des feuiells de Posidonia oceanica: modification de la méthode de. Zieman. Bot. Mar. 26, 35-43.

Cebrian, J., Duarte, C.M., 1994. The dependence of herbivory on growth rate in natural plant communities. Funct. Ecol. 8, 518525.

Kenworthy, W.J., Currin, C.A., Fonseca, M.S., Smith, G., 1989. Production, decomposition and heterotrophic of seagrass Halophila decipiens in a submarine canyon. Mar. Ecol. Prog. Ser. 51, 277-290.

Libes, M., 1986. Productivity-irradiance relationship of Posidonia oceanica and its epiphytes. Aquat. Bot. 26, 285-306.

Marsh, J.A., Dennison, W., Albert, R.S., 1986. Effects of temperature on photosynthesis and respiration in eelgrass (Zostera marina). J. Exp. Bio. Ecol. 101, 257-267.

Pergent-Martini, C., Raimondino, V.R., Pergent, G., 1995. Nutrient impact on the Posidonia oceanica seagrass meadows: preliminary data. Mar. Life 5 (2), 3-9.
Romero, J., 1989. Seasonal pattern of Posidonia oceanica production: growth, age and renewal of leaves. In: Boudouresque, C.F., Meinesz, A., Fresi, E., Gravez, V. (Eds.), Proceedings of the Second International Workshop on Posidonia Beds, October 7-11, 1985. GIS Posidonie, Ishia, Italy, pp. 63-67.

Sand-Jensen, K., 1977. Effect of epiphytes on ellgrass photosynthesis. Aquat. Bot. 3, 55-63.

Sand-Jensen, K., Borum, J., 1983. Regulation of growth of eelgrass (Zostera marina L.) in Danish coastal waters. Mar. Technol. Soc. J. 29, 29-35.

Sand-Jensen, K., Borum, J., 1984. Epiphytes shading and its effect on photosynthesis and diel metabolism of Lobelia dortmanne L. during the spring bloom in a Danish lake. Aquat. Bot. 20, 109-119.

Twilley, R.R., Kemp, W.M., Staver, K.W., Sevensen, J.C., Boynton, W.R., 1985. Nutrient enrichment of estuarine submersed vascular plant communities. 1. Algal growth and effects on production of plants and associated communities. Mar. Ecol. Prog. Ser. 23, 179-191. 